I $00 \mathrm{~kg}$, the ranking of $70 \mathrm{p}$. I oo of the animals varied less than Io ranks). From $85 \mathrm{~kg}$ live weight large differences were observed between breeds for criteria such as fattening and increase in backfat according to live weight. This pointed out the difficulty of using the same coefficients of performance fitting for several breeds.

\author{
III. - CARCASS AND MEAT QUALITY
}

\title{
Backfat androstenone content in entire male pigs of the large white breed: Variations according to social conditions during rearing
}

\author{
M. BONNEAU, B. DESMOULIN \\ Station de Recherches sur l'Élevage des Porcs \\ I.N.R.A., $7835^{\circ}$ Jouy-en-Josas (France)
}

The influence of social conditions during rearing on the variations in backfat androstenone content according to live weight was studied in two experiments. In the first one 34 entire male pigs were compared according to a $2 \times 2$ factorial design: the animals were reared in individual or collective pens either with or without visual and olfactive contact with gilts of the same age.

In the second experiment 20 entire male pigs were reared in contact with gilts either in individual or in collective pens. A radio immunoassay of androstenone was performed twice for each animal: First in a biopsy of backfat made at $80 \mathrm{~kg}$ live weight and then in a sample of backfat taken from the carcass. The pigs were slaughtered at $95 \mathrm{~kg}$ live weight in the first experiment and at $107 \mathrm{~kg}$ in the second one.

At $80 \mathrm{~kg}$ live weight (approximately i5o days of age) the mean androstenone was low $(0.3 \mathrm{I} \mu \mathrm{g} / \mathrm{g}$ in the first experiment and $0.4 \mathrm{I} \mu \mathrm{g} / \mathrm{g}$ in the second one $)$, but the variability was already quite large. When animals were slaughtered at an early stage $\left(95 \mathrm{~kg}\right.$ and ${ }^{6} 67$ days in the first experiment), the mean androstenone content was only $0.55 \mathrm{\mu g} / \mathrm{g}$ with a high variability (range 0.23 to $2.55 \mathrm{~kg} / \mathrm{g}$ ). When pigs were slaughtered at a later stage ( $107 \mathrm{~kg}$ and I 89 days in the second experiment), the mean androstenone content was higher (I.27\% g/g; range $0.2 \mathrm{I}$ to $5.13 \mu \mathrm{g} / \mathrm{g}$ ). If considering the individual vatiation according to live werght one can distinguish between two groups of animals:

- for 32 p. roo (first experiment) to $4^{\circ}$ p. roo (second experiment) of male pigs, there was no variation between the two stages,

- for the others (68 to $60 \mathrm{p}$. I 00 of animals), backfat androstenone content increased. However there were very large individual variations in the rate of increase.

At $80 \mathrm{~kg}$ live weight, the backfat androstenone content was not affected by the social conditions during rearing. At $95 \mathrm{~kg}$ (slaughter weight in the first experiment) no influence of the social conditions on the mean androstenone content was observed; however the proportion of animals exhibiting no increase in androstenone content between 80 and $95 \mathrm{~kg}$ was significantly higher when male pigs were reared without contact with females. At ro7 kg (slaughter weight in the second experiment) the mean androstenone content was significantly higher when animals were reared in collective pens.

In both experiments there was no relationship between backfat androstenone content and production parameters (feed intake, growth performance, feed efficiency). Coefficients of correlation between androstenone and carcass characteristics were not significant in the first experiment. In the second one, where the androstenone content was higher, a positive significant 
relationship was observed between androstenone and parameters closely related to the proportion of muscle in the carcass.

\title{
Total or partial dissection of pig carcasses. Signification of EEC references
}

\author{
B. DESMOULIN, R. CHALIER, P. POMMERE'T \\ I.N.R.A., Station de Recherches sur l'Élevage des Porcs \\ $7835^{\circ}$ Jouy-en-Josas (France) \\ I.T.P., Centre Expérimental de Pen Arlan Maxent \\ 35380 Plélan-le-Grand (France)
}

A total of 445 pig carcasses with a net weight of 70 to $90 \mathrm{~kg}$ and a mean composition of $x=48.2$ p. 100 muscles $(s x=6.03)$ were dissected according to the EEC method. The estimations based on the composition of cuts were made according to the pieces used (partial dissection) and to the accuracy of the dissection procedure (simplified dissection) $\mathrm{X}^{1}$ being the percentage of muscles only, $\mathrm{X}^{2}$ the percentage of muscles plus intermuscular fat, $\mathrm{X}^{3}$ that of meat without external fat but with bones.

The main results were the following:

1) After complete dissection of ham and loin + backfat the EEC reference relative to the percentage of muscle of the whole carcass was calculated with a residual error of $0.66 \mathrm{p}$. I muscle.

Total weight of muscles for the whole ham + loin with backfat allowed to control $98.7 \mathrm{p}$. I of the variance of the total weight of carcass muscles according to the following equation:

2) The simplified dissection led to the following estimations of the $\mathrm{EEC}$ reference.

The percentage of lean + internal fat $\left(\mathrm{X}_{2}\right)$ in ham and loin with backfat produced a residual error of I.OO p. Ioo muscles. The absence of trimming of internal fats overestimated by $3 . \mathrm{I}$ to $3.3 \mathrm{p}$. Ioo the percentage of muscles in fat pigs (threshold $40 \mathrm{p}$. 100) as compared with lean pigs (only $55 \mathrm{p}$. IOO of the EEC table).

The percentage of meat without external fat but with bones $\left(\mathrm{X}_{3}\right)$ of all cuts produced a residual error of $\mathrm{I} .44$ to $\mathrm{I} .7 \mathrm{I}$ p. Ioo muscles. Deboning of ham reduced considerably the estimation error. Tables indicating the correspondance between the EEC reference and the composition of the main cuts were established. They may contribute to a rapid arbitrage of grading problems. This could result in a more harmonious application of FEF regulation.

\section{Relationship between anatomical composition and ham conformation}

\author{
B. L. DUMONT, O. SCHMITT, T. BOULLEAU, J. LEFEBVRE \\ I.N.R.A., Laboratoive de Recherches sur la viande \\ $7835^{\circ}$ Jouy-en-Josas (France) \\ I.N.R.A., Labovatoire de Génétique Factorielle \\ 78350 Jouy-en-Josas (France)
}

The relationships between anatomical composition of ham (tissue percentages in the cut, percentage of each muscles within ham musculature) and conformation were studied. Conformation was defined by an objective index calculated from measurements taken on the profiles of the outlines of ham images.

Seventy-six pigs of various conformation and live weight ( 90 to $140 \mathrm{~kg}$ ) were considered. 